\title{
Könyvszemle
}

SIPOS JÚLIA GONDOZÁSÁBAN

\section{KVALITATÍV KUTATÁSOK MAGYARORSZÁGON: A MÓDSZERTŐL A SZEMLÉLETIG}

Csaknem egy időben jelent meg egy-egy vezető magyar humán tudományi szemle kvalitatív kutatásokat bemutató válogatása: a „Beszédes hallgatás” a Szociológiai Szemle 2017. évi 2., és „A kvalitatív kutatás új szenzibilitása” a Magyar Pszichológiai Szemle 2018. évi 1. számában. Az alábbiakban e két tanulmánycsokor bemutatására és értékelésére vállalkozunk.

Milyen kvalitatív kutatásokat végeznek és miként a pszichológusok és a szociológusok napjainkban Magyarországon? Saját közvetlen tartalmukon kívül, miként értékeljük a kutatások e nyalábjait mint a magyar tudomány fejleményeit? Milyen általánosabb trendekre következtethetünk ebből a humán tudományok módszertani törekvéseiről és filozófiai tájékozódásáról?

Németh Krisztina bevezetö tanulmányában áttekinti, hogy a Beszédes hallgatás szerzőit milyen episztemológiai, metodológiai, interpretációs és etikai kérdésfelvetések foglalkoztatják. Megállapítja, hogy dilemmáik a csend, a hallgatás, az elhallgatás, az eltakart valóságok fogalmai, jelentései és társas, társadalmi kontextusai köré szerveződnek. Bár nem hangsúlyozza, érdemes kiemelni, hogy e problémák szempontjából a bemutatott kvalitatív kutatások különös relevanciáját az adja, hogy a hagyományosabb kvalitatív elemzési módok számára nem hozzáférhetők, a föként önbevalláson alapuló kvantitatív megközelítések pedig létezésükről is csak közvetve képesek számot adni.

Zombory Máté írása a kulturális traumaelmélet kritikája. Soshana Feldman egy háborús bünös tárgyalásához, illetve az egyik tanú elájulásához kapcsolódó értelmezéseit a traumametafora kulturális kiterjesztése, a pszichoanalitikus koncepciója, illetve annak dekontextualizált felhasználása, s a történeti időtapasztalat változása felől ragadja meg. Michel Foucault-ra támaszkodva megállapítja, a traumáról való hallgatás és beszéd nem individuális vagy pszichológiai okokra vezethető vissza, hanem a beszéd feltételeinek és lehetőségeinek átalakulásához: a diszkurzív normák, keretek változásához kötött.

Vigvári András munkájában különbséget tesz a hallgatás, elhallgatás indirekt és direkt formái között, kitér ezek módszertani és etikai következményeire, elsősorban a módszertan és a kutatási kontextus illeszkedésére, a kutatói pozícióra, a 
kutató tágabb társadalmi kontextusának beemelésére, illetve etikai dilemmákra helyezve a hangsúlyt.

Virág Tünde a változó kutatói szerepekre és helyzetekre reflektál egy tabunak számító jelenség kapcsán, melyre roma családok külföldi munkavállalásával kapcsolatos migrációs stratégiáit, illetve a munkavállalás informális formáit vizsgáló terepmunkája során bukkant. A tanulmány a módszertani repertoár alakulását mutatja be a kutatók alakította interjúhelyzettől a kutatás alanyai által formált és irányított, számukra tudásfölényt, illetve az egyenrangúság érzését biztosító informális beszélgetésekig. Ahogy a valóság tabusítása a közösségi normáknak megfelelően jön létre, a titkok kimondása is a diszkurzivitás közösségi alakzatait követi.

Katona Noémi tanulmánya episztemológiai irányultságú, a kutatói pozícióra, a kutatói pozíció kutatására, a kutató és a kutatás alanya között létrejövő diskurzusban konstruálódó narratívákra, a kimondás és elhallgatás dinamikájára összpontosít. Berlini prostituáltak között végzett etnográfiai terepmunkájának bemutatása során kitér a kutató hatalmi pozíciójára, a segítő és kutatói szerep váltakozásából vagy éppen összemosódásából adódó szerepkettősség tudáskonstruáló szerepére, a prostitúciót övező társadalmi normák, a hallgatás, a szégyen és a stigmatizáció diszkurzív jellegére éppúgy, mint a szexmunkát és prostitúciót tematizáló akadémiai diskurzus kutatói attitűdre gyakorolt hatására.

Durst Judit munkája ugyancsak a kutatói pozíció episztemológiai szerepét, a terepkutatás módszertani kérdéseit, valamint az értelmezés alakulásának és befejezetlenségének tényezőit tematizálja, ugyanakkor tovább is lép annál. Egyrészt beemeli a rendkívüli eseményt, mint az informális gazdaságot mozgató szegénység és kilátástalanság feltárulásának aktusát, amely a helyi diskurzus elmozdulásának legfőbb szervezője lesz, másrészt reflektál arra az akadémiai, civil, politikai és más szereplők által szervezett társadalmi közegre, melyben a nyilvánosságra hozott adatok fogadtatása, értelmezése a szereplők szándékai és érdekei szerint müködtetett diskurzus(ok)ban történik.

A Beszédes hallgatást még néhány tartalmas könyvismertetés teszi teljessé.

Az „új szenzibilitás” kifejezést az 1980-as években, egy sajátos képzőművészeti attitüd megragadására és értelmezésre használták, s elsődlegesen Hegyi Lóránt kiállításszervezői és elméleti munkásságához kapcsolódik. De mi az „új szenzibilitás" Rácz József, Kassai Szilvia és Kaló Zsuzsa, A kvalitatív kutatás új szenzibilitása szerkesztői szerint ma, a pszichológiai kutatásokban? Az új szenzibilitást szerintük az adatfelvétel és -elemzés kvalitatív módja helyett egyfajta episztemológiai kíváncsiság jellemzi, valamint az, hogy hívei a neutralitás követelményét/illúzióját feladva nyíltan értékelvủ módon, a tárgy, a módszer, a kutató és a résztvevő szerepére reflektálva próbálnak új belátásokra jutni, eközben szem elött tartják a kutatás következményeit, mind a tudomány és a praxis viszonylatában, mind a társadalmi tevékenységre vagy éppen a társadalmi igazságtalanságok felszámolására gyakorolt hatásában. 
Sallay Viola és Martos Tamás tanulmánya az egyik legelterjedtebb kvalitatív elemzési eljárás, a lehorgonyzott elmélet történeti és tudományfilozófiai áttekintésére, irányzatainak bemutatására vállalkozik. A lehorgonyzott elméletet illusztráló empirikus kutatásukban krónikusan beteg hozzátartozóval élő családok érzelmi önszabályozását vizsgálják az otthon érzelmi alaprajza interjúra támaszkodva. A lehorgonyzott elmélet ihlette kutatást a szubjektív valóság megragadásának igénye, a kutatói önreflexivitás, az adatfelvétel és értelmezés kölcsönös egymásra hatása, az adatokból alkotott fogalmak kontextusának és kölcsönkapcsolatainak megjelenítése jellemzi.

Csabai Márta az esettanulmány tudománytörténeti státusának változását és a módszer alkalmazásával kapcsolatos dilemmákat járja körül különböző tudományterületeken, a kulturális antropológiától az orvostudományon át a pszichológiáig és pszichiátriáig. Kitér a szociális konstruktivista megközelítés esettanulmányt átformáló hatására, melynek következtében az esetmódszert az emberi viselkedés és a társas interakciók legszélesebb körére kezdték alkalmazni, s bemutatja az esettanulmány módszer kortárs megközelítéseit is. Megállapítja, hogy az esettanulmány felépítése, múfaji sajátosságai a kulturális és társadalmi tradíció, a hatalmi struktúrák és a tudományos elvárások - tehát alapvetően diskurzusok - függvényében alakul.

Berán Eszter és Unoka Zsolt a pszichoterápia hatásmechanizmusát vizsgálja. Kiindulópontjuk, hogy a kliens narratív perspektívájának változása az élettörténeti epizódok elmondása során az interakciós folyamat eredménye, ahogy az annak hatására létrejövő narratív szelf változása is. Ily módon a terapeuta narratív perspektívaváltásai az élettörténet perspektívájának átalakítását (re-, illetve ko-konstrukcióját) eredményezik, s ezáltal terápiás változást idézhetnek elö. A szelf-narratívát Kenneth J. Gergen nyomán társas konstrukciónak tekintik, elemzésükhöz a narratív és a diszkurzív pszichológia számos belátását termékenyen alkalmazzák. A narratív perspektíva s a diskurzusjelölők funkcionális és strukturális értelmezésére alapozzák elemzésüket, amely egy pszichoterápia többszintủ diskurzuselemzése. Munkájukban ugyanakkor nem reflektált, hogy a pszichoterápia során a kliens és terapeuta között létrejövő hierarchikus viszony is hatást gyakorol(hat) a diszkurzív folyamatra, mint ahogy a terapeuta által létrehozott - akár ki nem mondott - diagnózis is.

B. Erdős Márta krízisintervenciós hívások narratív elemzésére vállalkozik, széles elméleti hátteret felvonultatva. A tanulmány a tudomány és a praxis egymásra hatásának, illetőleg a praxis egyénre és társadalomra gyakorolt hatásának kiváló példája, hiszen a krízishelyzetek narratív elemeit a krízishelyzet társadalomba, közösségbe ágyazottsága, a krízis diszkurzív helyzete, valamint a kliens és segítő diskurzusa felől, a segítő folyamat hatását is figyelembe véve tárgyalja. A narratív identitás elméleteire és a narratív pszichológia külföldi és hazai eredményeire támaszkodva részletesen elemzi a krízisnarratívák nyelvi 
szerveződését. Célja nem pusztán leíró, eredményeit a praxisban látja alkalmazhatónak.

Dúll Andrea és szerzőtársai kvantitatív és kvalitatív módszerekkel végzett környezetpszichológiai kutatásukat mutatják be. Építészhallgatók és térlaikus egyetemi hallgatók mentális térképábrázolásait hasonlítják össze. A kutatás az egyén és környezete tranzakcióit emeli ki. Vizsgálódási területévé a kép, a képiség válik, többszörösen is, hiszen a mentális térképeket megjelenítő rajzokra összpontosít. A rajzok tranzakcionális elemzésének célja a környezeti kommunikáció, a szociofizikai kontextus dinamikájának ábrázolása, a megszerzett ismeretek felhasználása a környezetmérnöki tervezői praxisban. Ezzel Dúll és társai a legszorosabb értelemben vett diszkurzív pszichológiához kapcsolódnak, a diskurzust szélesebb értelemben, az egyén és környezeti kultúrája összefüggésében értelmezve.

Kassai Szilvia, Pintér Judit és Rácz József tanulmánya az interpretatív fenomenológiai analízis (IPA) alkalmazását mutatja be szerhasználók és felépülök körében. A kutatás William James identitáskoncepciójára támaszkodik, melynek értelmében a szelf az élmények közegében folyamatosan keletkezik és alakul, az egyén érzéseinek és a hozzájuk kapcsolódó értelmezéseinek sokaságából hozza létre önmagát, választja ki aktuális identitását. Az IPA voltaképpen egy narratív folyamatkutatás, melynek keretében a függő és felépülő személy identitáskonstrukciója, illetve annak változása nyomon követhetö, ezáltal a felépülés folyamatában az egyén támogatható. A szerzők kitérnek a pszichoaktív szerek és a szintetikus kannabinoidok használatának eltérő identitásformáló hatására, kutatásuk az ellátórendszer számára is megfogalmaz tanulságokat.

Vajon a szemlékben bemutatott sokféle kvalitatív kutatás beilleszthető egy régebben elterjedt mintázatba, mely szerint módszertani kérdésekről van szó, amit egyebek közt a kvalitatív versus kvantitatív oppozíció is jellemez? Vagy a kvalitatív kutatásokat nem csupán módszertani szempontok azonosítják, hanem a társadalomtudományi kutatások sajátos szemléleti keretét tanúsítják? A két szemle fent áttekintett tanulmányai megítélésünk szerint e második lehetőség mellett szóló tanúságtételek, $\mathrm{s}$ a társadalomtudományos pszichológia és a szociológia egy sajátos szemléletét képviselik, a kvalitatív kutatások új nyelvi játékának kialakulását tanúsítják.

Miről is van szó? A kvalitatív kutatás egyre inkább a társadalomban élő emberre irányuló tudástermelés olyan módját jelöli, melyet kimondva-kimondatlan a társas konstrukcionizmus szemlélete jellemez, ami egybefonódik az ahhoz illesztett megismerési móddal, az értelmezéssel. Számos módon megfogalmazást nyert mindez, mi itt a katolikus Charles Taylorra hivatkozunk, aki szerint az ember önértelmezö állat, „self-interpreting animal”. Látnunk kell, hogy ez az önértelmezés nem a kutató kizárólagos sajátja. A kutatás tárgya, illetve alanya is önértelmező lény, s önértelemzése és a változó környezetéhez való alkalmazkodási törekvései egymással összefonódnak, folytonosan változnak. Ez kívülről tekintve 
akadálya a megismerésének, mivel arra utal, hogy nem alkothatók általános törvényszerüségek az emberről, egyebek közt, mert az önmagára vonatkozó tudás megváltoztathatja az ember viselkedését - a kapcsolódó dinamikát Robert K. Merton a szociológiában, Robert Rosenthal a pszichológiában jellemezte önbeteljesítő jóslatként. Ám a megismeréséhez vezető eszközökkel is ellát: az önértelmezés megnyilvánul, így téve lehetővé az önértelmezés rekonstrukcióját. És itt lép müködésbe a kvalitatív kutatás. Számára az alanyok önértelmezése, ágenciája és önmeghatározása nem probléma, nem kiküszöbölendo „zaj”, hanem maga a ,,jel”.

A kvalitatív kutatás terminus, megítélésünk szerint, túllépett azon, hogy pusztán módszertani eszközök egy csoportját jelezze. Jelentésváltozás zajlik - új nyelvi játék kialakulásának vagyunk tanúi. A kvalitatív kutatást konstituáló önértelmezést az agykutató, aki természeti törvényszerüségekben gondolkodik, esetleg elhessegetheti magától, de a pszichológus vagy a szociológus nem engedheti meg magának ezt a luxust, mert ezzel azt kockáztatja, hogy üres manipulátorrá vagy a laikusok számára semmitmondóvá válik, megtagadván az ismerd meg önmagad szókratészi feladatát.

(Beszédes hallgatás. Szociológiai Szemle, 2017/2; A kvalitativ kutatás új szenzibilitása. Magyar Pszichológiai Szemle, 2018/1.)

Csekő Csilla

PhD-hallgató Pécsi Tudományegyetem Pszichológia Doktori Iskola

Bodor Péter

egyetemi tanár Eötvös Loránd Tudományegyetem Társadalomtudományi Kar Szociológia Tanszék 